Research article

\title{
Floristic composition and vegetation analysis of Hulikal Ghat region, central Western Ghats, Karnataka
}

\author{
Vinayaka K. S. ${ }^{1}$ and Krishnamurthy Y. L. ${ }^{2}$ \\ ${ }^{1}$ Department of Botany, Kumadvathi First Grade College, Shikaripura-577427, Shimoga, Karnataka \\ ${ }^{2}$ Department of Studies and Research in Applied Botany, Kuvempu University, \\ Shankaraghatta-577451, Shimoga, Karnataka
}

*Corresponding Author: ks.vinayaka@gmail.com

[Accepted: 11 December 2016]

\begin{abstract}
Forest ecosystem is one of the most important terrestrial ecosystems of the world. Biodiversity is a dynamic process among living organisms exhibiting different degrees of activities according to their placement in nature. The present study was carried out in the Hulikal forest $\left(13^{\circ} 46^{\prime} 15^{\prime \prime} \mathrm{N}\right.$ to $13^{\circ} 42^{\prime} 30^{\prime \prime} \mathrm{N}$ and $75^{\circ} 1^{\prime} 30^{\prime \prime} \mathrm{E}$ to $\left.75^{\circ} 5^{\prime} 15^{\prime \prime} \mathrm{E}\right)$ Hosanagar taluk of Shimoga district, Karnataka. Study areas are located at an elevation range of 560 MSL to 800 MSL above the sea level and it is having highest rainfall receiving area in Karnataka. The Hulikal forest consists of almost evergreen forest with swamp/marshy vegetation. Major tree species found in the study are Litsea floribunda, Garcinia gummi-gutta, Cinnamomum verum, Myristica malabarica etc. with shrubs like Carissa carandas, Croton malabaricus, Memecylon malabaricum, Maesa indica, Leea indica etc. In Hulikal forest a total of 2172 samples were recorded from 30 quadrats. They are belongs to 231 species and 60 families, among them 53 herb, 51 shrubs, 31 climbers and 96 were trees species. Lower diversity of herbaceous plants is present here because of closed canopy. The Hulikal forest showed more canopy trees with evergreen forests. The trees are tall and long in height. Fahrenheitia zeylanica is an important species with Impotence Value Index (IVI) of 10.4 and basal area of 0.7. The Shannon diversity index value of the herbaceous species, climbers and tree species were $3.6,3.8 \& 4.3$ respectively. The study revealed that this region is very rich in species composition.
\end{abstract}

Keywords: Forest ecosystem - Tree diversity - Diversity indices - Hulikal - Evergreen.

[Cite as: Vinayaka KS \& Krishnamurthy YL (2016) Floristic composition and vegetation analysis of Hulikal Ghat region, central Western Ghats, Karnataka. Tropical Plant Research 3(3): 654-661]

\section{INTRODUCTION}

Forests are renewable resources encompassing millions of living organisms both plants and animals living in perfect harmony with nature. Forest ecosystem is one of the most important terrestrial ecosystems of the world. Biodiversity is a dynamic process among living organisms exhibiting different degrees of activities according to their placement in nature. Tropical forests often referred to as one of the most special diverse terrestrial ecosystem (Ashish et al. 2006). The Western Ghats are considered as the $18^{\text {th }}$ mega biodiversity centre of the world and it is recognized as one of the biological 'Hot spots' of the world. These forests are unique ecosystem due to their rich plant and animal diversity (Mayer et al. 2000). Correct inventorization and assessment of biodiversity in different habitats is also necessary for evolving a long term strategy for rehabilitation of endangered species in similar alternate habitats when original habitat gets destroyed (Ali et al. 2006). The forest types in India ranges from thorny scrubby jungle to moist ever green forest along with moist grasslands and characteristic shoal vegetation. In each of these different types of forests, a very diverse plant species are found growing naturally. Identification of species and their diversity is a difficult task and it is virtually impossible to have a complete inventory of Indian biodiversity. However, there has been a limited investigation to characterize species at regional levels. Western Ghats is threatened by the catastrophe and anthropogenic activities to larger extent are frequently responsible for endangering species through various ways such as 
degradation and fragmentation of habitats over exploitation and effect of pest and diseases. The diversity of Western Ghats regions of Karnataka depleted in fast rate. For example, in the Uttar Kannada regions the forest area has condensed from $8000 \mathrm{~km}^{-2}$ to $600 \mathrm{~km}^{-2}$ in about 40 years (Myens et al. 2000, Ananth \& Potter 1997). This constitutes an enormous loss of biodiversity in a small area over a short period of time. So for the conservation and sustainable development of the Western Ghats, elaborate and long term research study is necessary. Biodiversity losses have been alarmed in the developing countries in the tropics (FAO 1990) estimated that about $60 \%$ of the tropical forests of the world have already been destroyed. As for the biodiversity of Western Ghats is concern limited attempts has been made by certain group of researcher to document floristic diversity (Ramkumar \& Parthasarthy 2001). There are certain areas within the Western Ghats which remains to be explored for their biodiversity. The endemic species are in threat due to damming and clearing diversity of KMTR Western Ghats region (Ganesan 2002). Forest degradation not only cause reduction in biodiversity but also leads to the change in the community composition (Prem Kumar \& Uma Nandri 2003).

Climate is probably the most important determinant of vegetation patterns globally and has significant influence on the distribution, structure and ecology of forests. The global assessment has shown that future climate change is likely to significantly impact forest ecosystem (Ravindranath et al. 2006). Species population shows two kinds of mature phase, where the topography is raised and gently sloping the vertical structure of the stand is discontinuous and where the stand is lower vertical structure of the stand is continuous (Pascal \& Pellissier 1996, Utkarsh et al. 1998, Pelissier 1998, Seetharam et al. 2000). Increasing human population in the last few decades, demanding development in various areas has resulted directly or indirectly in sudden and often for reaching disturbances in natural ecosystem (Raizada \& Vaid 1957). Hulikal forest has been facing many problems, various mining activities; power projects, luxuriant growth of exotic species and others are rendering the existence of rich floristic diversity. In this attempt we carry out the vegetational analysis of the area.

\section{MATERIALS AND METHODOLOGY}

Study area

The present study was carried out in the Hulikal state forest $13^{\circ} 46^{\prime} 15^{\prime \prime} \mathrm{N}$ to $13^{\circ} 42^{\prime} 30^{\prime \prime} \mathrm{N}$ latitude and $75^{\circ} 1^{\prime} 30^{\prime \prime}$ E to $75^{\circ} 5^{\prime} 15^{\prime \prime}$ E longitude of Hosanagar taluk of Shimoga district, Karnataka. Study areas are located at an elevation range of $560 \mathrm{MSL}$ to $800 \mathrm{MSL}$ above the sea level. The rainfall varies from 850 to $900 \mathrm{~mm}$ per annum with a temperature range of 15 to $30^{\circ} \mathrm{C}$. Hulikal is recently recognized as highest rainfall area in south India. Most of the rainfall occurs in the month of June to September carried by south west monsoon different weather parameters which are recorded in study areas during the last 10 years (2003-2013) are given (Fig.1).

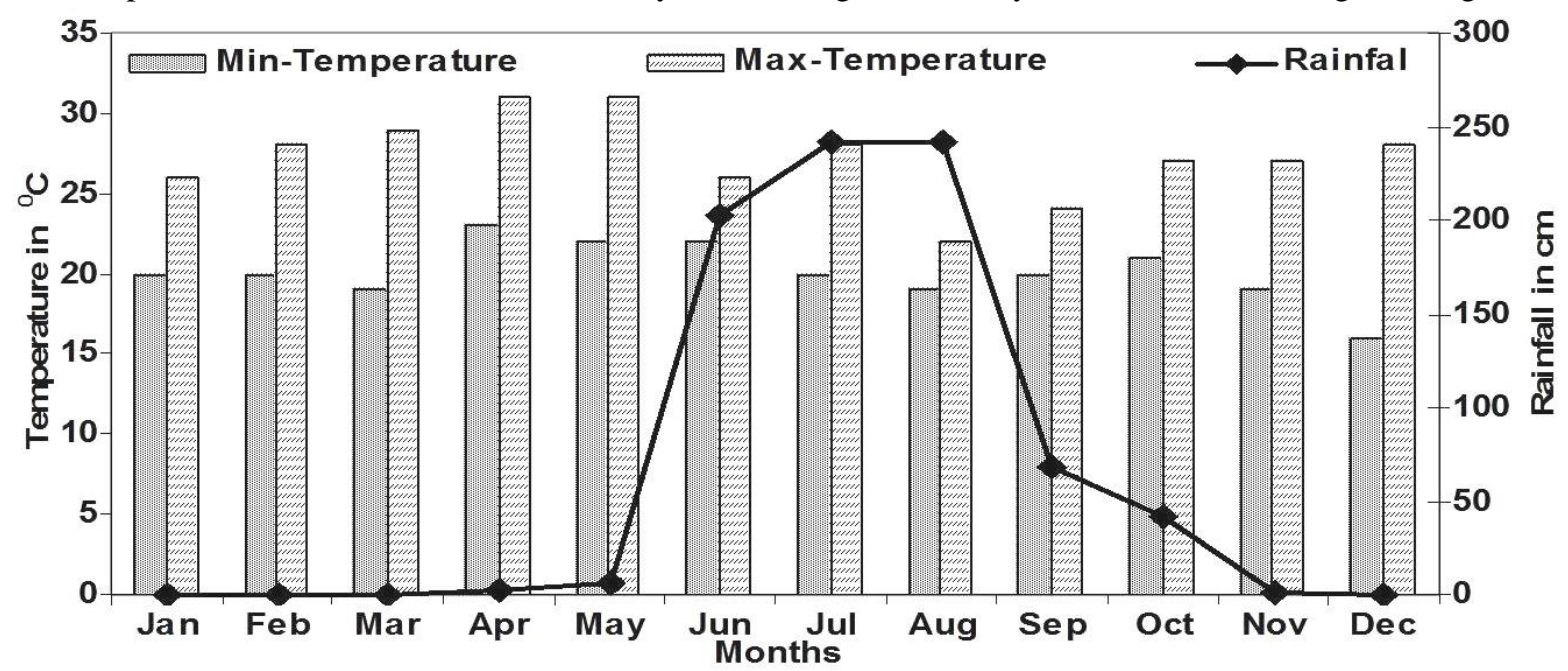

Figure 1. Average Rainfall and Temperature at Hulikal Forest region (2003-2013).

\section{Vegetation type}

The Hulikal forest consists of almost all evergreen forest with swamp/marshy vegetation (Fig. 2). Major tree species found in the study are Litsea floribunda, Garcinia gummi-gutta, Cinnamomum verum, Myristica malabarica etc., with shrubs like Carissa carandas, Croton malabaricus, Memecylon malabaricum, Maesa indica, Leea indica etc., and herbs like Habenaria longicorniculata, Impatiens scapiflora, Costus speciosus, Cassia tora, Mimosa pudica etc., as major ground species. 


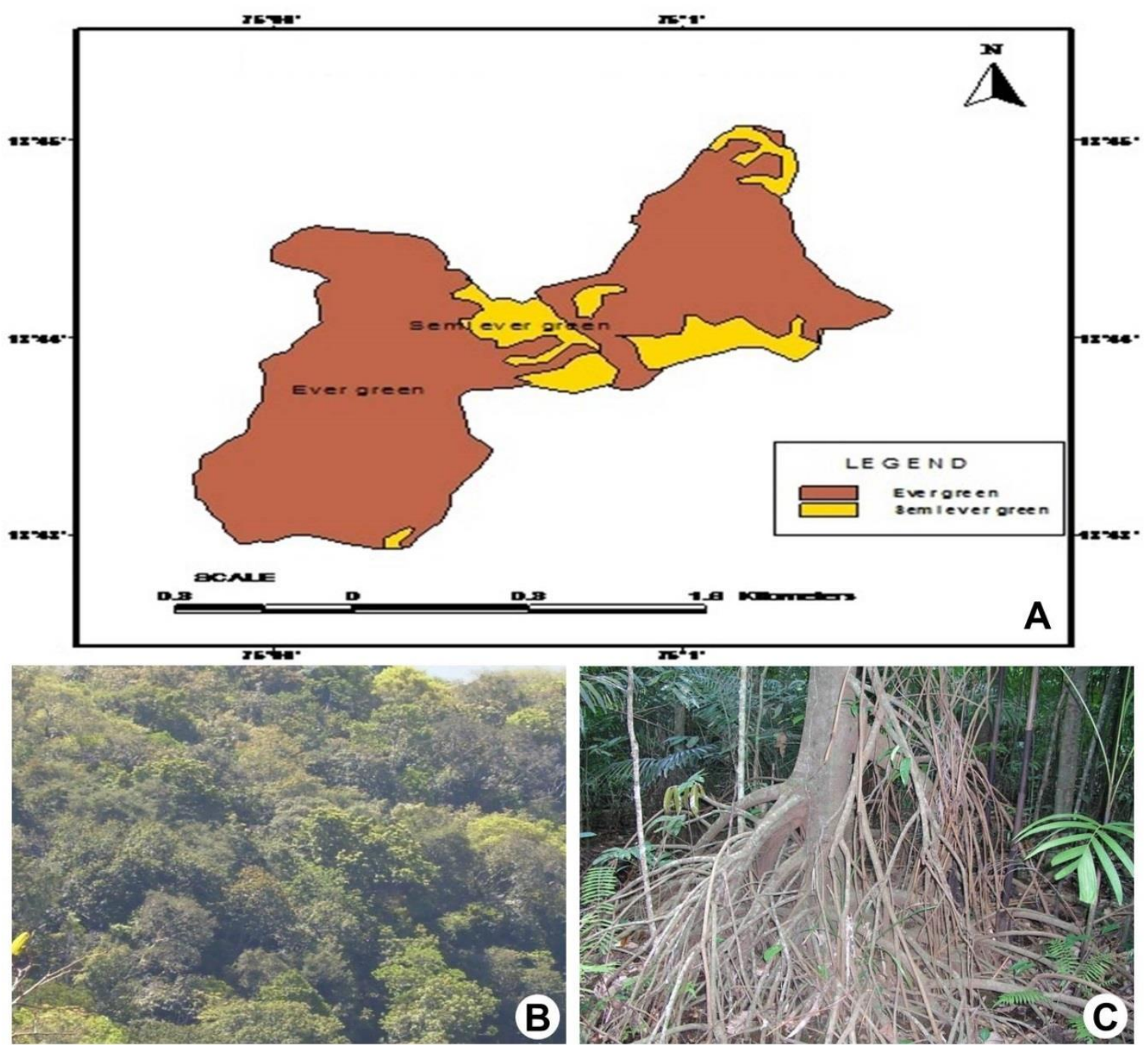

Figure 2. Forest types in Hulikal Ghat region: A, GIS map showing forest types; B, View of evergreen forest; C, View of Swamps.

\section{Vegetation Analysis}

The study site comprises of different types of vegetation. A total of 30 belt transects each measuring $25 \times 5 \mathrm{~m}$ were laid in Hulikal forest in which plants were documented. All the plants above $10 \mathrm{~cm} \mathrm{GBH}$ (girth at breast height) were considered as trees whose girth has been measured for the basal area. Shrubs and herbs were recorded in $5 \mathrm{~m} \times 5 \mathrm{~m}$ and $1 \mathrm{mx} 1 \mathrm{~m}$ were identified and confirmed by using various region floras (Gamble 1935, Pascal \& Ramesh 1987, Yoganarasimhan \& Razi 1981, Ramaswamy 2001, Neginhal 2004, Ganeshaiah et al 2002). The vegetational data was qualitatively and quantitatively analysed for abundance, density, frequency, dominance and basal area following (Cottam \& Curtis 1956). The Important value index (IVI) for the species was determined as the sum of relative frequency, relative density and relative dominance (Pielou 1975). Based on the data of the occurrence of species within the transects by Shannon's diversity index (H') and Simpson's diversity index were calculated as per (Magurran 1988).

Density and relative density is calculated as

$$
\begin{gathered}
\text { Density }=\frac{\text { Total number of individual species }}{\text { Total number of transects studied }} \\
\text { Relative Density }=\frac{\text { Number of transects in which species studied }}{\text { Total number of transects studied }} \times 100
\end{gathered}
$$

Frequency and relative frequency is calculated as

$$
\text { Frequency }=\frac{\text { Number of transects in which species studied }}{\text { Total number of transects studied }}
$$




$$
\text { Relative Frequency }=\frac{\text { Frequency of a species }}{\text { Total frequency of all species }} \times 100
$$

Abundance is calculated as

$$
\text { Abundance }=\frac{\text { Total number of individuals of the species in all the transects }}{\text { Total number of transects in which species has occurred }}
$$

Relative dominance is calculated by

$$
\text { Relative dominance }=\frac{\text { Total basal area of the species in all the transects }}{\text { Total number of basal area of all the species in all the transects }}
$$

Basal area is calculated as

$$
\text { Basal area }=\mathrm{BA}=\pi \mathrm{r}^{2}
$$

Important value index (IVI) is calculated as

$$
\text { IVI }=\text { Relative frequency }+ \text { Relative Density }+ \text { Relative BA }
$$

Based on the data of the occurrence of species in the transects by Shannon's diversity index was calculated which is represented below

$$
\begin{aligned}
H^{\prime} & =-\Sigma \text { pi lnpi } \\
\text { where } \mathrm{pi} & =(\mathrm{ni} / \mathrm{N})
\end{aligned}
$$

Other diversity indices such as Simpson's values (D), Simpson's diversity index (E), was calculated as follows.

$$
\mathrm{D}=\sum \frac{\mathrm{ni}(\mathrm{ni}-1)}{\mathrm{N}(\mathrm{N}-1)}
$$

Where $\mathrm{ni}=$ Number of individuals of the $\mathrm{i}^{\text {th }}$ species; $\mathrm{N}=$ Total number of individuals

\section{RESULTS}

In Hulikal forest a total of 2172 individuals recorded from 30 quadrats. They belong to 231 species and 60 families. Lower diversity of herbaceous plants is present because of closed canopy. The Impatiens scapiflora is high diversity represented by 20 individuals with IVI of 9.0 and Girardinia diversifolia, Mimosa pudica shows IVI of 8.7 and 7.0 respectively. Rauvolfia serpentina shows less frequency with IVI of 1.2 (Table 1). Shrubs

\begin{tabular}{|c|c|c|c|c|c|c|}
\hline S.N. & Herb Species & Family & $\begin{array}{l}\text { Number of } \\
\text { individuals }\end{array}$ & RD & $\mathbf{R F}$ & IVI \\
\hline 1 & Impatiens scapiflora Heyne ex Roxb. & Balsaminaceae & 20 & 4.1 & 5.0 & 9.0 \\
\hline 2 & Girardinia diversifolia (Link) Friis & Urticaceae & 20 & 4.1 & 4.6 & 8.7 \\
\hline 3 & Mimosa pudica $\mathrm{L}$. & Fabaceae & 17 & 3.5 & 3.5 & 7.0 \\
\hline 4 & Justicia montana (Nees.) Wall. & Acenthaceae & 15 & 3.1 & 3.9 & 7.0 \\
\hline 5 & Curculigo orchioides Gaertner & Zingiberaceae & 15 & 3.1 & 3.9 & 7.0 \\
\hline 6 & $\begin{array}{l}\text { Chassalia curviflora var. ophioxyloides (Wall.) Deb \& } \\
\text { B.Krishna }\end{array}$ & Rubiaceae & 16 & 3.3 & 3.2 & 6.5 \\
\hline 7 & $\begin{array}{l}\text { Ophiorrhiza rugosa var. prostrata (D.Don) Deb \& } \\
\text { Mondal }\end{array}$ & Rubiaceae & 12 & 2.4 & 3.5 & 6.0 \\
\hline 8 & Zingiber cernuum Dalzell & Zingiberaceae & 12 & 2.4 & 3.5 & 6.0 \\
\hline 9 & Triumfetta rhomboidea $\mathrm{N}$. Jacq. & Tiliaceae & 13 & 2.7 & 3.2 & 5.8 \\
\hline 10 & Laportea interrupta (L.) Chew & Urticacae & 12 & 2.4 & 2.8 & 5.3 \\
\hline
\end{tabular}
diversity is represented by Lantana camara with 30 individuals and IV of 10.3 which is followed by Maesa indica, Leea indica with IVI of 9.8 and 8.3 respectively. Maytenus emarginata shows less IVI of 0.8 (Table 2). This forest region shows less number of climbers. Naravelia zeylanica is an important species with IVI of 14.8 followed by Thunbergia mysorensis, Piper hookeri with IVI of 14.0 and 13.8 respectively. Clematis gouriana shows less IVI of 1.5 (Table 3).

Table 1. Herb species composition with their Re-density, Re-frequency and Importance Value Index in Hulikal Forest. (RDRelative Density, RF-Relative Frequency, IVI- Importance Value Index) 
Table 2. Shrub species composition with their Re-density, Re-frequency and Importance Value Index in Hulikal Forest. (RD- Relative Density, RF-Relative Frequency, IVI- Importance Value Index)

\begin{tabular}{|c|c|c|c|c|c|c|}
\hline Sl. No. & Shrub Species & Family & $\begin{array}{l}\text { Number of } \\
\text { individuals }\end{array}$ & RD & $\mathbf{R F}$ & IVI \\
\hline 1 & Lantana camara L. & Verbinaceae & 30 & 5.0 & 5.3 & 10.3 \\
\hline 2 & Maesa indica (Roxb.) DC. & Myrsinaceae & 27 & 4.5 & 5.3 & 9.8 \\
\hline 3 & Leea indica (Burm. f.) Merrill & Vitaceae & 24 & 4.0 & 4.3 & 8.3 \\
\hline 4 & Memecylon malabaricum Cogn. & Melastomaceae & 30 & 5.0 & 3.3 & 8.3 \\
\hline 5 & Rotheca serrata (L.) Steane \& Mabb & Verbinaceae & 20 & 3.3 & 4.7 & 8.0 \\
\hline 6 & Pandanus canaranus Warb. & Pandanacae & 20 & 3.3 & 4.3 & 7.6 \\
\hline 7 & Chromolaena odorata (L.) King \& Robinson & Asteraceae & 30 & 5.0 & 1.3 & 6.3 \\
\hline 8 & Scleropyrum pentandrum (Dennst.) Mabb. & Santalaceae & 21 & 3.5 & 2.7 & 6.1 \\
\hline 9 & Memecylon umbellatum Burm. f. & Melastomaceae & 18 & 3.0 & 3.0 & 6.0 \\
\hline 10 & Psydrax dicoccos Gaertn. & Rubiaceae & 15 & 2.5 & 3.0 & 5.5 \\
\hline
\end{tabular}

Table 3. Climber species composition with their Re-density, Re-frequency and Importance Value Index in Hulikal Forest. (RD- Relative Density, RF-Relative Frequency, IVI- Importance Value Index)

\begin{tabular}{lllllll}
\hline \multicolumn{1}{c}{ Sl. No. } & \multicolumn{1}{c}{ Climber Species } & Family & $\begin{array}{c}\text { Number of } \\
\text { individuals }\end{array}$ & RD & RF & IVI \\
\hline 1 & Naravelia zeylanica (L.) DC. & Rhamnaceae & 25 & 7.1 & 7.7 & 14.8 \\
2 & Thunbergia mysorensis (Wight) T. Anderson & Acanthaceae & 22 & 6.3 & 7.7 & 14.0 \\
3 & Piper hookeri Miq. & Piparaceae & 23 & 6.6 & 7.2 & 13.8 \\
4 & Rubia cordifolia L. & Rubiaceae & 19 & 5.4 & 4.3 & 9.7 \\
5 & Piper hymenophyllum (Miq.) Wight & Piperiaceae & 17 & 4.8 & 4.8 & 9.7 \\
6 & Dioscorea bulbifera L. & Dioscoraceae & 21 & 6.0 & 3.4 & 9.3 \\
7 & Dioscorea pentaphylla L. & Dioscoraceae & 19 & 5.4 & 3.8 & 9.3 \\
8 & Gymnema sylvestre (Retz.) R. Br. ex Schultes & Asclepadeaceae & 14 & 4.0 & 4.8 & 8.8 \\
9 & Celastrus paniculatus Willd. & Celastraceae & 15 & 4.3 & 4.3 & 8.6 \\
10 & Schefflera venulosa (Wight $\&$ Arn.) Harms & Araliaceae & 13 & 3.7 & 4.3 & 8.0 \\
\hline
\end{tabular}

Table 4. Tree species composition with their Re-density, Re-frequency and Importance Value Index in Hulikal Forest. (BA- basal Area, RD- Relative Density, RF-Relative Frequency, Re-BA- Relative basal area, IVI- Importance Value Index)

\begin{tabular}{|c|c|c|c|c|c|c|c|c|}
\hline S.N. & Tree Species & Family & $\begin{array}{l}\text { Number of } \\
\text { individuals }\end{array}$ & $\mathbf{B A}$ & RD & $\mathbf{R F}$ & $\operatorname{Re}-\mathbf{B A}$ & IVI \\
\hline 1 & Fahrenheitia zeylanica (Thw.) Airy Shaw & Euphorbiaceae & 30 & 0.7 & 4.1 & 4.5 & 1.7 & 10.4 \\
\hline 2 & Hopea ponga (Dennst.) Mabberly & Dipterocarpaceae & 30 & 0.1 & 4.1 & 3.6 & 0.2 & 8.0 \\
\hline 3 & Murraya paniculata (L.) Jack & Meliaceae & 22 & 0.5 & 3.0 & 3.4 & 1.1 & 7.5 \\
\hline 4 & Garcinia xanthochymus Hook. f. ex T. Anderson & Clusiaceae & 25 & 0.2 & 3.4 & 3.6 & 0.4 & 7.5 \\
\hline 5 & Leea indica (Burm. f.) Merrill & Leeaceae & 19 & 0.8 & 2.6 & 2.7 & 1.8 & 7.1 \\
\hline 6 & Holigarna arnottiana Hook. f. & Anacardaceae & 16 & 1.0 & 2.2 & 1.8 & 2.3 & 6.3 \\
\hline 7 & Madhuca neriifolia (Moon) H. J. Lam & Sapotaceae & 19 & 0.3 & 2.6 & 3.0 & 0.7 & 6.3 \\
\hline 8 & Litsea floribunda (Blume) Gamble & Lauraceae & 14 & 0.8 & 1.9 & 1.8 & 1.8 & 5.6 \\
\hline 9 & Aporosa lindleyana (Wt.) Baill. & Euphorbaceae & 14 & 0.4 & 1.9 & 2.7 & 0.9 & 5.5 \\
\hline 10 & Heynea trijuga Roxb. ex Sims & Meliaceae & 9 & 1.0 & 1.2 & 1.8 & 2.3 & 5.3 \\
\hline
\end{tabular}

The Hulikal forest showed more canopy trees with evergreen forests. The trees are tall and long in height. Fahrenheitia zeylanica is an important species with IVI of 10.4 and basal area of 0.7. Lagerstroemia lanceolata, Mangifera indica, Symplocos cochinchinensis had the basal area of 1.0. Hopea ponga, Murraya paniculata showed IVI of 8.0 and 7.5 respectively. Cassia fistula showed less basal area and less IVI of 0.1 and 0.8 respectively (Table 4). 


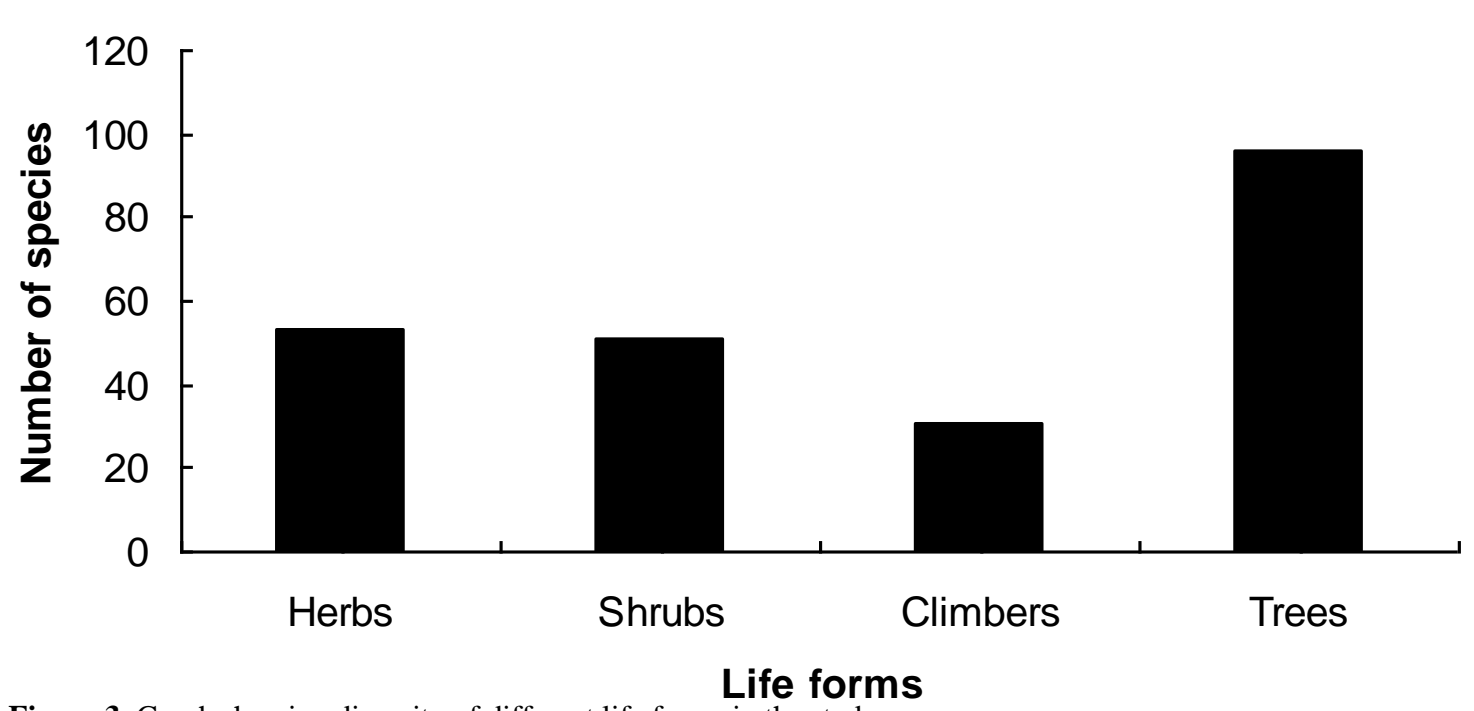

Figure 3. Graph showing diversity of different life forms in the study area.

The Hulikal forest had 53 herb species, 51 shrubs, 31 climbers and 96 trees species they are representing a total of 2172 individuals of 60 families this indicates Hulikal forest is rich in floristic diversity (Fig. 3). The Shannon diversity index of herbaceous species of Hulikal forest is 3.8. The diversity index of the climbers and tree species like Shannon index value of Hulikal is 4.3. The Simpson diversity index similarly shows following results (Table 5). Hulikal Herbaceous, Shrubs and climbers diversity is $25 \%, 73 \%$ and $69 \%$ respectively. The tree diversity of Hulikal is $81 \%$ and this indicates Hulikal forest have rich in tree species diversity.

Table 5. Showing the diversity index vales.

\begin{tabular}{lrrr}
\hline \multirow{2}{*}{ Life forms } & \multicolumn{3}{c}{ Diversity indices } \\
\cline { 2 - 4 } & Shannon $\left(\mathbf{H}^{\mathbf{I}}\right)$ & Simpson $(\mathbf{D})$ & Simpson (1/d) \\
\hline Herbs & 3.9 & 0.019 & 51.03 \\
Shrubs & 3.8 & 0.025 & 39.84 \\
Climbers & 3.3 & 0.040 & 25.00 \\
Trees & 4.3 & 0.015 & 67.11 \\
\hline
\end{tabular}

\section{DISCUSSION}

The present study revealed the species richness in the Hulikal forests of central Western Ghats region. The study revealed that this region is very rich in species composition. The number of individuals species in the area is formed to be very high when compared to Mudumalai deciduous forest which accounts for 71 species in 50 hectare permanent plot (Sukumar et al.1992) it was moderate against the transect study at 3.82 hectare done in Kalakad-Mundanthurai Tiger reserve (Ganesh et al. 1996 ). It is also higher diversity when compared to the total of 74 species recorded in Kudremukh National Park (Nagaraja et al. 2005). They also mentioned that Achranthes aspera is the dominant herb, Lantana camara is the dominant shrub, Ichnocarpus frutenscens is the dominant climber and also represented by rich in epiphytic, orchids and mosses diversity same pattern of vegetation occurs in Hulikal forest region.

Conservation of the whole spectrum of biological diversity is a new challenge. This calls for an in-depth understanding of the patterns of distribution of many different parameters that can be used to characterise abundance and diversity at different taxonomic hierarchies and at differential spatial scales. Then such an understanding has to be applied towards assigning conservation values to particular taxa, localities and habitats.

\section{CONCLUSION}

The indiscriminate use and over exploitation of natural plant wealth for minor causes results in deterioration of ecosystem and a great loss to mankind. The developing countries concentrate on the development of industries and technique. This will lead to a great decrease in global biodiversity. The Hulikal forest of Western Ghats, Hosanagar region shows high level of plant diversity compared with the other forests in the Western Ghats. The total of one hectare vegetative plot from these forests. The present study is highlighting the rich species composition of the forest and fragmentation of the forest for the different commercial plantation is threatening the forest balance. While in case of Hulikal state forest, Government prone developmental activities 
like dam construction across the river Varahi near Hulikal and clearing of forest for the power lined are damaging the plant diversity. Several forest management activities are needed for the conservation of diversity existing in these forests and also there is a need of educating the people regarding the loss of biodiversity from these forests. In the context, present study would serve as a baseline data for the effective forest management for the policy makers.

\section{ACKNOWLEDGMENTS}

Authors are thankful to the Chairman, Department of Applied Botany, Kuvempu University, Shankarghatta, Shimoga and Secretary, Swamy Vivekananda Vidya Samsthe, Shikaripura, Shimoga and Karnataka Forest Department for permitting and encouraging the carryout the present work.

\section{REFERENCES}

Ali S, Rao GR, Divakar KM, Sreekantha, Vishnu DM, Subash Chandran MD, Gururaja KV, Joshi NV \& Ramachandra TV (2006) Ecological Status of Sharavathi Valley Wildlife Sanctuary. In Ecological Conservation E-NEWS, Issue-I, at: http://ces.iisc.ernet.in/hpg/envis/sdev.

Ananth Pur K \& Potter D (1997) Implementation of Joint Forest Management in Uttara Kannada District (19941996): do NGOs matter? GECOU Working Paper 9, Milton Keynes: Open University.

Ashish K, Bruce GM \& Ajai S (2006) Tree species diversity and distribution patterns in tropical forests of Garo hills. Current Science 91(10): 1370-1380.

Cottam G \& Curtis JT (1956) The use of distance measured in phyto-sociological sampling. Journal of Ecology 37: 451-460.

FAO (2001) Global forest resources assessment 2000. Main report, FAO Forestry Paper 140. Rome.

Gamble SS (1935) Flora of the Presidency of Madras. Botanical Survey of India, Calcutta.

Ganesan R (2002) Evergreen forest swamps and their plant species diversity in KMTR South Western Ghats, India. Indian Forester 120: 1351-1359.

Ganesh T, Ganesan R, Soubadra Deraj M, Darroly D \& Bawa S (1996) Assessment of plant biodiversity of a mid elevation evergreen forest of Kalakad Mundanthurai. Tiger. Reserve Western Ghats, India. Current Science 71(5): 379-391.

Ganeshaiah KN, Sagar K \& Uma Shankar R (2002) Floral resources of Karnataka. A geographic perspective. Current Science 83(7): 810-813.

Ghate U, Joshi NV \& Madhav G (1998) On the patterns of tree diversity in the western ghats of India. Current Science 75(6): 594-603.

Magurran AE (1988) Ecological Diversity and its Measurement. Princeton University Press, New Jersey, pp. 1179.

Mayer N, Russel A, Mittermeler C, Mittermeler GG, AB Da Fonseca and Jennifer Kents. (2000) Biodiversity hotspots for conservation priorities. Nature 403: 853-858.

Muthu Ramkumar \& Parthasarthy N (2001) Tree liana relationship in a tropical evergreen forest at Varagular an analysis. Western Ghats, India. Journal of Tropical Ecology 395-409.

Nagaraja BC, Somashekar RK \& Bunty Raj M (2005) Tree species diversity and composition in logged and unlogged rainforest of Kudremukh National Park, South India. Journal of Environmental Biology 26: 627634.

Neginhal SG (2004) Forest trees of South India. Navbarath Press, Seshadripuram, Bangalore, pp. 1-420.

Pascal JP \& Pellissier R (1996) Structure and floristic composition of a tropical evergreen forest in south west India. Journal of Tropical Ecology 190-216.

Pascal JP \& Ramesh BR (1987) A field key to the trees and lianas of the evergreen forests of the Western Ghats (India). Institute Francais de Pondichery, India, $221 \mathrm{p}$.

Pelissier R (1998) Tree species pattern in 3 contrasting plots of a southern Indian tropical moist evergreen forest. Journal of Tropical Ecology 14-16.

Pielou EC (1975) Ecological Diversity. John Wiley and Sons Inc.

Jha PK \& Uma N (2003) Biodiversity measurement in forests of various canopy density. Indian Forester 129: 1391-1394.

Raizada MB \& Vaid KM (1957) Glimpses of the vegetation of Otakamandal. Indian Forester 83: 641-646. 
Ramaswamy SN, Radhakrishna Rao M \& Govindappa D A (2001) Flora of Shimgoa district Karnataka. Directorate of Prasaranga, University of Mysore, Mysore, $113 \mathrm{p}$.

Ravindranath NH, Joshi NV, Sukumar R \& Saxena A (2006) Impact of climatic change on forests in India. Current Science 90(3): 354-361.

Seetharam YN, Halesh C \& Vijay (2000) Structure and floristic composition of a dry deciduous forest at Bidar district, Karnataka. Indian Forester 23: 241-247.

Sukumr R, Dattaraja HS, Suresh HS, Radhakrishnan J, Vasudeva R, Nirmal S \& Joshi NV (1992) Long term monitoring of vegetation in a tropical deciduous forest in Mudumalai, South India. Current Science 64(9): 608-616.

Yoganarasimhan SN \& Razi BA (1981) Flora of Chikmagalur district, Karnataka, India. International Book Distributors, Dehradun. 